25. Additional Notes on some Eruptive Rocks from New Zeatand. By Frank Rutlex, Esq., F.G.S. (Read April 4th, 1900.)

\title{
[Prate XXVII.]
}

The rocks described in this paper were, with two or three exceptions, collected by Mr. James Park, F.G.S., and reached me just before the completion of the paper on the rhyolites of the Hauraki Goldfields, read last year before this Society. ${ }^{1}$ A few of these specimens came from the area dealt with in that paper, but a considerable number of them are from other localities in the North Island, including several from Rotorua, which are interesting as affording recent examples of solfataric action.

For the estimations of the total silica in these rocks I have to thank my friend Mr. Philip Holland, F.I.C., F.C.S., by whom they were made. Lantern-slides of some of the more typical rocksections have been very kindly prepared for me by Mr. Frederick Chapman, A.L.S., F.R.M.S., of the Royal College of Science, South Kensington.

The present paper may, to some extent, be regarded as a continuation of that on the Hauraki rhyolites, but although certain specimens, about to be described, bear a tolerably close resemblance to some of those dealt with in the last paper, many of them, when examined microscopically, are found to present points of interest which render them worthy of special notice.

These rocks vary so much in their structural details that no attempt will be made to adopt any systematic order in their description, except that the specimens from Rotorua will be treated consecutively at the end of the paper.

$\mathrm{H}_{21}$. Waihi.-A pale-grey, lithoidal rhyolite, with little dark-green crystals suggestive of pyroxene, and small colourless crystals of felspar.

Under the microscope the rock is seen to be a rhyolite with an irregularly-undulating fluxion-banding, the lithoidal character being due to the development partly of globulites, partly of spherulitic growths. The latter are best seen in ordinary transmitted light, when magnified about 150 diameters. Between crossed nicols the spherulitic structure is very obscure and, owing to the bright illumination of only a few fibres or rods in each spherulite, gives rise to the appearance of a rather sparse dissemination of microlites through a partly isotropic groundmass. Small porphyritic crystals and fragments of augite are present in the rock. The prismatic angle, measured in a section normal to the vertical axis of one of these crystals, was $87^{\circ}$. The augites are more or less corroded.

1 'Notes on the Rhyolites of the Hauraki Goldfields' by J. Park \& F. Rutley, with Chemical Analyses,by P. Holland, Quart. Journ. Geol. Soc. vol. 1v (1899) p. 449.

Q.J. G. S. No. 223. 
Porphyritic crystals and fragments of felspar also occur. These, from their extinction-angles, may. in some cases, be referred to sanidine, in others to andesine. The section also contains small crystals and grains of magnetite and some limonite, the latter probably pseudomorphous after pyrites. Ilmenite may likewise be present in small quantity, but the evidence upon this point is unsatisfactory.

$\mathrm{H}_{22}$. Waihi.-The specimen shows conchoidal fracture, and is scratched with difficulty by a knife-blade. It is dark brown, and has a resinous lustre, but there are paler spots and markings upon which the resinous lustre is absent. The rock has the general appearance of ordinary semi-opal.

Under the microscope, in ordinary transmitted light, the section varies from nearly colourless to pale yellow, and in places is almost orange-yellow, with deep brown spots which sometimes are surrounded by annular borders of like colour but slightly separated from the nuclear spots. Only parts of the section appear to be isotropic when viewed between crossed nicols, a considerable portion of it being traversed by irregularly-reticulating, anisotropic streaks, which raguely suggest the possibility of an original vegetable structure.

Since the label, forwarded with the specimen, states that it occurred in rhyolite, it may possibly have been a fragment of silicified wood, ${ }^{1}$ taken up and more or less altered by a lavastream. Dr. G. J. Hinde, F.R.S., to whom I submitted the section, kindly examined it and, while reserving any definite opinion upon it, favoured me with a letter, from which the following statements are extracted :-

'I feel much doubt whether any wood structure is now shown in it. Whether it may have been wood originally, and has had the structure destroyed, is another question ; but considering the very perfect preservation of the structure in fossilized wood, I do not think that such has been the case with this specimen.'

He further adds,

' I do not see how wood is likely to have been preserved if caught up and enveloped in a recent condition by a lava-flow; it might possibly not be destroyed if it were at the time silicified.'

$\mathrm{H}_{23}$. Water-race, Waihi.-A pale pinkish-grey rock, containing dark-grey angular fragments, ranging from almost microscopic dimensions to more than an inch in diameter.

The rock is seen under the microscope to be a pumiceous rhyolite-tuff containing crystals of plagioclastic felspars, mostly oligoclase and andesine. Quartz and biotite are present in small quantity. The section shows one fragment of quartz which has been cracked into three pieces. They have been slightly.separated, and the middle one somewhat displaced, so that it has a different orientation from that of the two terminal portions. A fragment of

1 In Hochstetter's 'New Zealand' (1863) transl. E. Sauter (Stuttgart, 1867), it is stated on p. 119 that silicified wood occurs 'in the creeks in many localities where siliceous rocks are decomposing.' 
a porphyritic felspar-crystal shows zonal banding in polarized light, and the extinction-angles of the twin lamellæ indicate that it is bytownite. The pumiceous portions of this section show the characteristic fibrous structure, which is, however, sometimes hard: to distinguish from the fluxion-banding of rhyolitic lavas. Apart from the fragments of crystals, the general mass of the rock is isotropic.

$\mathrm{H}_{24^{*}}$ Tauranga Bridge.-A pale pinkish-grey rock with minute crystals of glassy lustre, small dark specks, and pale fibrouslooking fragments.

In thin section the rock is seen, under the microscope, to be essentially a pumice-tuff, containing a few small fragments, apparently of andesite, fragments of plagioclastic felspar, corroded quartz, with small sporadic scales of biotite and specks of pyrites.

$\mathrm{H}_{2 \tilde{a}^{\circ}}$ Tahua, Mayor or Obsidian Island.-A black obsidian, appearing as a very pale brownish glass on thin edges, and showing very perfect conchoidal fracture.

Under the microscope, the section is seen to contain numerous gas-inclusions, often elongated and of very irregular shape, sometimes sharply angular in form, at others oral or fusiform. A few colourless microlites, which for the most part give approximately straight or very low extinction-angles, are no doubt felspars. There are also a few very pale-green microlites, which in some instances give an extinction-angle of $19^{\circ}$ to the direction of elongation. The latter appear to be extremely narrow in proportion to their length.

Prof. F. W. Hutton ${ }^{1}$ has described an obsidian from this locality, in which he detected similar hornblende-microlites, and adds that there are ' no trichites nor microvesicles.' He also describes a reddish-brown pitchstone from Mayor Island, which exhibits a pumiceous character.

$\mathrm{H}_{26}$. Tahua or Mayor Island.-A black obsidian with some small greyish-white specks. It has a less marked conchoidal fracture and a less perfect vitreous lustre than the preceding specimen. This is due to the presence of the very numerous gas-pores, which, with a pocket-lens, may be seen pitting the fractured surfaces.

Under the microscope these gas-inclusions are seen to vary greatly in form and dimensions, and it is only here and there that, when fusiform or tubular, they indicate the direction of flow (Pl. XXVII, fig. 1). Very small crystals, mostly mere microlites of felspar, are plentiful in this section. They sometimes form little aggregates, which are apparently the white specks visible in the hand-specimen. There are also many microlites of hornblende present: these occasionally show extinction-angles up to $19^{\circ}$ or more with the axis of elongation. The section also shows part of a pyroxene-crystal,

1 'The Eruptive Rocks of New Zealand' Journ. Roy. Soc. N.S.W. vol, xxiii (1889) p. 121. 
which, in convergent polarized light, gives a partial biaxial interference-figure of positive sign.

$\mathrm{H}_{27}$. Waitekauri.-A bluish-grey ritreous rock, much resembling some of the perlitic rocks of Schemnitz in Hungary. Under the microscope there is no apparent fluxion-banding, and(with the exception of eyelash-like trichites) the glassy matter is almost wholly free from microlites; but numerous porphyritic crystals of felspar, mostly sanidine or oligoclase, quartz often corroded, biotite, and occasional small specks of magnetite, are present.

The perlicity of this section is extremely well-defined, and is remarkable as serving, in certain spots, to illustrate the transition from straight to curvilinear cracks. As pointed ont many years ago, ${ }^{1}$ the curvilinear perlitic cracks are almost invariably packed between straight or approximately straight fissures, and are not traversed by the latter.

In parts of this section cracks may be seen spanning transversely the areas between rudely parallel and comparatively straight fissures. These transverse cracks are, in some cases, almost straight, while in other instances they show a distinct tendency to describe perlitic curves. When this is the case, the perlitic bodies are elongated between the rungs of the ladder-like systems of cracks, as shown in Pl. XXVII, fig. 2. Such a scalariform perlicity has, so far as I am aware, not hitherto been noticed.

The rock, apart from its porphyritic crystals and its fissures, is remarkably isotropic.

Mr. Philip Holland has kindly estimated the silica in this rock. It amounts to 73.45 per cent. This sets at rest any doubt about the rock being an obsidian, the Hungarian perlitic rocks, which. this somewhat resembles, being in many cases hyalodacites, which are characterized by a lower percentage of silica.

$\mathrm{H}_{2 \psi^{*}}$. Waitekauri.-Apparently a breccia composed of dark-grey, yellowish-brown, and white fragments. The rock is generally very dark, even black in parts, with a granulated appearance and with small dark specks which have a vitreous lustre, the specimen slightly resembling a fine-grained schorlaceous rock.

Under the microscope the smaller fragments are seen to be felspar, mostly andesine and labradorite. There are often, however, crystals of sanidine, some of them twinned on the Carlsbad typo and, in one instance, on the Baveno type. Occasionally the plagioclastic felspars show zonal banding, the extinction-angles indicating that the outer zone is andesine, while the inner portion is labradorite. Crystals of augite and of a rhombic pyroxene, as well as pyrites, occur in this section, together with fragments of andesite and rhyolite, the latter sometimes spherulitic. These spherulites are of the brown, microfelsitic kind. All these fragments of rocks

\footnotetext{
1 'On some Structures in Obsidian, Perlite, \& Leucite' Monthy Microsc. Journ. vol. xv (1876) pp. 179 et seqq. \& pl, cxxxiv.
} 
and minerals are embedded in rhyolite, the fluxion-banding of which sweeps around them.

Everything seems to indicate that the rock is a tufaceous rhyolitic lava, which has either taken up fragments of andesite and rhyolite in its lower portion, or else has been erupted during a shower of lapilli upon its surface. The rhyolite of the lava-stream is practically isotropic.

$\mathrm{H}_{29^{*}}$ Waitekauri.-A brown semi-vitreous rock, with small dark and light crystals or fragments : the groundmass, where weathered, appearing pale-grey, with small white and brown crystals.

Under the microscope, this is seen to be a rhyolite with a damascened or corrugated fluxion-banding, and containing many crystals and fragments of felspars-chiefly oligoclase and andesine, augite, rhombic pyroxene, olivine, and pyrites. The marked difference between the unweathered and the weathered portions of the hand-specimen is not very clearly seen in the section when it is riewed in ordinary transmitted light; but in reflected light it is found to be due to a selective alteration (kaolinization) of certain streaks, so that, in the most weathered part of the rock, a very large amonnt of kaolin is present : while in the comparatively unweathered part much less opaque white matter is visible, since only a limited portion of the fluxion-banding has been kaolinized. This clearly shows that certain bands in a rhyolite may be more readily attacked by atmospheric agency than others, not necessarily because they differ in chemical composition, although some slight differences may exist, as pointed out by Prof. Iddings ${ }^{1}$; but rather because it may often be noted that there are differences in grain or texture in the alternating fluxion-bands. It seems only reasonable to infer that the same kind of difference in solubility would exist between such bands as exists in the solubility of any mineral substance when coarsely and finely powdered.

The rock may be called a tufaceous rhyolite. The crystals and fragments in it have evidently been derived from andesites which occupy a considerable tract north of Waitekauri. ${ }^{2}$

$\mathrm{H}_{30}$. Mataura.-A pale-grey rock, with very delicate banding, and showing small colourless scales. It is sufficiently hard to resist the point of a penknife.

A section of this rock, when examined under the microscope, does not seem to present any distinct characters suggestive of a lava, but rather those of a laminated tuff, composed of exceedingly fine volcanic dust in which a considerable amount of tridymite occurs, mostly in irregularly-segregated plates, forming bands and patches. Where free from tridymite the section is nearly isotropic. It appears to be a much-altered rhyolitic tuff. Microscopically it bears some resemblance to certain earthy volcanic tuffs met with

1 'Obsidian Cliff' 7th Ann. Rep. U.S. Geol. Surv. 1885-86 [1888] p. 274.

2 See map of the Hauraki Goldfields, by James Park, Quart. Journ. Geol. Soc. vol. Iv (1899) pl. xxxi. 
in Auvergne. The section contains numerous colourless microlites and a few crystals of sanidine, also some opaque white matter forming small pseudomorphs after a mineral which appears to have crystallized in approximately octahedral forms. In one instance a fragment of an opaque black mineral is surrounded by a thin opaque white crust. This may possibly represent a superficial alteration of ilmenite into leucoxene.

Small fragments of rock are present, but not plentiful, in this section. They are so much altered that it is unsafe to express any opinion about them other than that they seem, for the most part, to have been derived from rhyolites.

The great hardness of the rock is to be attributed to the tridymite with which it is so abundantly impregnated.

$\mathrm{H}_{31}$. Waihi Beach ('older rhyolite' of Park).-A pale greyishwhite spherulitic rock, containing small dark specks and colourless crystals with a vitreous lustre, also a few dark micaceous-looking scales. The spherulites range from about $\frac{1}{8}$ inch in diameter to smaller dimensions.

Under the microscope, the rock appears to consist almost wholly of spherulites which seem originally to have been of the brown microfelsitic type. They are still brown, but are almost isotropic, in the centres perfectly so, but the peripheral portions usually transmit light very feebly between crossed nicols.

The spherulites often have polygonal boundaries, as though they had pressed against one another, and among them occur numerous porphyritic crystals and fragments of crystals, frequently showing very distinct evidence of corrosion. These porphyritic crystals may be recognized as quartz, felspars, biotite, and pyrites. The quartz appears to have been cracked and affected by heat. The felspars are all practically isotropic, and can consequently be identified by the forms of their sections alone. Biotite is not very plentiful in this rock: basal sections may be recognized by the approximately hexagonal forms giving angles of $60^{\circ}$, but in convergent polarized light no satisfactory interference-figure can be seen, since the crystals are rendered more or less opaque by partial alteration into limonite. One section transverse to the cleavage shows the characteristic pleochroism and absorption. The pyrites occurs in cubes, groups of cubes, and irregularly-shaped patches. The section is speckled by diminutive opaque erystals, many of which appear to be magnetite or pseudomorphs after that mineral.

One of the most interesting features of this section is, however, to be found in a small irregular area in which a coarse mosaic of felspar and quartz may be seen between crossed nicols. In convergent light the quartz shows partial uniaxial interference-figures, and, in one or two instances, a positive sign. The felspars also show partial interference-figures, a dark, curved brush sweeping diagonally across the field. This area in the section is, therefore, unquestionably felsite, so far as mineral constitution is concerned. Structurally it differs from an ordinary felsite in the circumstance 
Vol. 56.] ERUPTIVE ROCKS FROM NEW ZEALAND.

that there is a little nearly isotropic matter present among the grains of quartz and felspar : the seemingly isotropic matter being seen under a higher power ( 140 diameters) to be filled with globulites and margarites, and to show very decided double refraction in places.

These apparently isotropic patches are not really so, but are diminutive fragments, evidently derived from the spherulites which bound this felsitic area. In order to prove that this is the case, one has only to examine the margin of this small area, when it will be seen that those parts of the spherulites abutting on it are gnawed away and disintegrated along the fibration of the spherules in the most irregular manner. Small pieces of the spherules have become detached and taken up in the felsitic matter, and the latter, moreover, may be seen occupying peripheral parts of spherules which, where they remain intact, are almost devoid of double refraction. Nearly in the middle of this felsitic area may be seen, in ordinary transmitted light, a well-defined circle, from the centre of which as though traced by fine pen-strokes, ridial markings are partly outlined. In polarized light, this ' sketch of a spherulite' breaks up into a number of irregular patches or grains, which constitute part of the surrounding felsite. (See Pl. XXVII, figs. 3 \& 4.)

If we endeavour to realize the various changes through which this small portion of the rock has passed before reaching its present condition, we have to consider :

(1) The rise and outpouring of a rhyolitic magma containing numerous already-formed crystals of felspar, quartz, etc., some entire, others broken, which are undergoing a process of superficial corrosion;

(2) As this lava solidifies rapidly, it becomes a glass or obsidian, containing the porphyritic crystals and fragments of earlier generation;

(3) At a subsequent period the glass becomes devitrified by the development of globulites and other microscopic bodies, and by the formation of spherulites, which originate at numerous points, incorporating in their growth a certain amount of the devitrified glass. These from their brown colour, their dimensions, and from the prevalence of globulites in them, may (from comparison with sections of similar rocks from the district) be presumed to have been microfelsite-spherulites. Doubtless, when first formed they wonld have exhibited such double refraction as spherulites of this kind are generally found to possess, and, as they continued to increase in size, the growth of their radiating fibres would become arrested by those of adjacent spherulites, in some cases along planes tangential to the mutually-approaching spheres, thus giving rise to the polygonal forms which the spherulites sometimes assume;

(4) Conditions supervened, such as may be accounted for in any active volcanic district, which resulted in this solidified spherulitic rock being again raised to a high temperature, one suffieiently high to deprive of their double refraction, not merely the spherulites, but also the earlierformed fragments and crystals of felspar ;

(5) The high temperature resulting from this secondary heating, probably assisted by water holding alkaline salts and other mineral matter in solution, appears to have further acted upon certain parts of the rock, probably along joints or on the walls of small cavities, thus decomposing and disintegrating the spherulites: such portions, on slow cooling, assuming the strnctural character of a coarse-grained felsite, while also possessing the mineral constitution of such a rock.

It appears that, in this case, the changes are mainly molecular, 
leading, in an extreme phase, to the obliteration of original structure and the ultimate development of a felsitic condition.

If such changes can be brought about in a rhyolitic lava of Tertiary age, little wonder can be felt at the occurrence of like changes in rhyolites of great geological antiquity. It $\in$ ven seems possible, if not probable, that some of the felsites which now yield no microscopic evidence that they were ever lavas, may originally have possessed structures which, had they been preserved, would have completely set at rest all doubt about their origin.

$\mathrm{H}_{32}$. Waihi Monument ('older rhyolite' of Park).-A yellowish rock with a spherulitic structure, and containing some small dark-green plates which are easily scratched: these appear to be chlorite pseudomorphous after biotite. The spherulites average between $\frac{1}{16}$ and $\frac{1}{8}$ inch in diameter.

Under the microscope, this appears to be a comparatively fresh or very slightly altered representative of the preceding rock from Waihi Beach $\left(\mathrm{H}_{31}\right)$. The spherulites, of which the rock is almost entirely composed, are, however, quite as doubly refracting as those that occur in the rocks of Omahu and Mercury Bay.

Very small black crystals and specks are common throughout the section. In most instances these may be regarded as magnetite. In reflected light no distinct evidence of the presence of pyrites can be detected.

The spherulites are often packed closely together, but when spaces exist between them, those spaces are filled with a colourless substance containing numerous microlites, which in most cases are colourless and give approximately straight extinctions. The colourless matter in which they lie is more or less isotropic, and mainly consists of scales, apparently of tridymite, with possibly some microfelsite.

The section contains a few porphyritic felspar-crystals, the largest measuring over $\frac{3}{8}$ inch in length. They contain many glass-inclusions, often show twin lamellæ, and appear in many instances to be labradorite. Some of them are much corroded. One of the largest porphyritic crystals gives an extinction-angle of $38^{\circ}$, and the partial interference-figure seen in convergent polarized light indicates the oblique emergence of one of the optic axes just outside the field. This may, therefore, be regarded as a section of anorthite parallel to the brachypinacoid. The crystal is traversed by irregular cracks, and contains many glass-inclusions.

The rock may be called a rhyolite, or preferably an obsidian, composed of microfelsitic spherulites with some porphyritic crystals of felspar.

$\mathrm{H}_{33^{*}}$ Waihi Beach.-A pale greenish-white rock with darker green mottling, containing a few small, micaceous-looking plates, and numerous little grains which have a vitreous lustre and occasionally show conchoidal fracture. The specimen is so hard that the point of a knife-blade barely makes any appreciable streak. 
Under the microscope the rock is seen to be a perlitic rhy olite, pervaded by a small and rather ill-defined spherulitic structure. There are also much larger spherulites sometimes forming aggregates. The double refraction of these larger spherulites is seen, when tested with teinte sensible No. 2 , to be positive, but the cross is often so broken up and distorted that it is then difficult to ascertain their optical sign with any certainty. The character of the smaller spherulites is still more difficult to recognize, but they also appear to be positive.

Cracked and corroded crystals and angular fragments of quartz are plentiful in this section, and there are also some porphyritic crystals of felspar: some of these being sanidine, others apparently andesine, the former preponderating. Porphyritic crystals of biotite also occur, often well-developed, but not very numerous. The green colour of the rock is probably due to the fine dust and microlites which pervade it. The latter extinguish parallel to their length, and are probably epidote.

\section{Rocks from Rotorua.}

In the Ninth Annual Report of the United States Geological Survey, 1887-88 [1889], there is a treatise on the 'Formation of Travertine \& Silicenus Sinter by the Vegetation of Hot Springs' by W. H. Weed, in which, after dealing very fully with the subject in its relation to the geysers and hot springs of the United States, some details are added concerning his examination of specimens of siliceous sinter from New Zealand. He states (op. cit. p. 673) that

'The siliceous sinters from Rotorua vary from pulverulent deposits of impure silica to dense, white opal sinters. Two of the specimens were evidently formed about spouting vents, showing the peculiar structure and beaded surface produced by the evaporation of spattered drops of water. Such sinters, to which the name of geyserite may be most properly applied, are very common about the Yellowstone geysers, occurring often in beautiful coralloidal forms, sometimes possessing a bright pearly lustre. The New Zealand specimens are parts of an old deposit formed in this way, and consist of numerous little pillars formed of many convex layers of pink and white silica, resembling a pile of minute caps, one upon another. This geyserite is wholly the result of evaporation, which adds film after film of glassy silica to the surface of the deposit, as often as wet by the steam or spray from the geyser.'

Mr. Weed further states (op. cit. p. 674) that

'Two of the specimens are of especial interest because their structure indicates that the algous life of the hot waters of Rotorua produced siliceous sinter.'

It appears, however, from comparison of this statement with that previously quoted, that the siliceous sinters of Rotorua can be formed without organic aid as well as with it. That Mr. Weed also regards the question of the deposition of these sinters from both points of view, is seen when be proceeds to say (op. cit. p. 676) :

- No information is obtainable relative to the comparative abundance of the .different types of sinter, but the presence of acid, and comparative scarcity of alkaline waters shown by the list of springs published by Dr. Hector, leads to 
the belief that algons sinter forms a sinaller proportion of the siliceous deposits than it does at most of the geyser-basins of the Yellowstone, where the waters are chiefly alkaline.'

Mr. Weed gives a brief account of the microscopic characters of some of the siliceous sinters of the Yellowstone, but remarks:

- Thin sections of siliceous sinters fail to show the origin and nature of the deposit as clearly as had been hoped':

and again (op. cit. p. 667),

' If many of the algous sinters fail to reveal an organic structure beneath the microscope, they are nerertheless easily distinguished from the more glassy and pearly sinters formed by evaporation.'

Again (op. cit. pp. 671-72),

- The physical differences in the unaltered sinters formed by evaporation and those of algous origin is generally quite marked, the former being translucent or vitreous, bard, and heary, while the algous sinter is opaque, white, and often chalk-like in appearance.'

The description given by $F$. von Hochstetter regarding the deposit formed by one of the hot springs on the Waikato is also of interest, as it is applicable to some of the specimens about to be described. He states that the deposit, like that of all the other springs near the Waikato, is siliceous, that, when recent,

' It is soft as gelatine, gradually hardening into a triturable mass, sandy to the touch, and finally forming, by the layers deposited one above the other, a solid mass of rock of a very variable description at different places, botb as to colour and structure. Here it is a radiated fibrous or stalky mass of lightbrown colour; there a chalcedony hard as steel, or a grey flint; at other places the deposit is white, with glossy conchoidal fracture like milk-opal, or with earthy fracture like magnesite.' 1

With these prefatory quotations, I may now proceed to describe some of the rocks from Rotorua, chiefly collected by Mr. James Park.

$\mathrm{H}_{38^{*}}$ Rotorua.-A bluish-grey rock, with feebly vitreous lustre and subconchoidal fracture. The specimen somewhat resembles a pale-grey pitchstone, and shows, where weathered, a whitish pulverulent crust.

Under the microscope, the rock is scen to consist of small fragments of pumice, with a considerable sprinkling of minute fragments of felspar and an occasional grain of quartz. Some of the felsparfragments show lamellar twinning and may be referred to andesine, but sanidine and oligoclase are also present. Viewed between crossed nicols, the section is seen to contain some perfectly isotropic matter which consists partly of pumice and partly of a cement of amorphous silica, while some feebly or partly anisotropic matter also belps to form the cement. In parts it is brown in ordinary transmitted light, while in reflected light it appears pink.

The rock is essentially a pumice-tuff, cemented and indurated. by silica derived from the hot springs so prevalent in the district.

$$
1 \text { 'New Zealand' transl. E. Sauter (Stuttgart, 1867) p. } 398 .
$$


The silica in this rock, when powdered and dried at $100^{\circ} \mathrm{C}$., has been found by Mr. Philip Holland to amount to 81.99 per cent.

$\mathrm{H}_{39}$. Rotorua.-A dark-grey rock with weak vitreous lustre, having dull pinkish-white patches and mottlings. The darker portion of the specimen shows small, irregularly-shaped cavities, and in colour, lustre, and fracture somewhat resembles a baked slate or porcellanite.

Under the microscope it is seen to be a fine pumiceous tuff, cemented by siliceous sinter or geyserite. The fragments of pumice are for the most part extremely small, little more than pumice-dust, but the section contains some larger fragments. The finely shredded pumice-fragments are suggestive of Mugge's bogenstruktur, or what Lane describes as 'concave ash.' ${ }^{1}$ A few fragments of felspar are present. Mr. Holland has kindly estimated the silica in this specimen, and finds that it amounts to 81.22 per cent., the rock having previously been powdered, and the powder dried at $100^{\circ} \mathrm{C}$.

The geyserite, which constitutes a considerable portion of the rock, is not perfectly isotropic, but feebly transmits a milky bluishwhite light between crossed nicols. This is also to be noticed in a section taken from a specimen of Icelandic geyserite, ${ }^{2}$ which has a weak milky appearance where the section is thin, but where thicker or less translucent the appearance is almost snow-white. ${ }^{3}$ That the milky or snow-white aspect between crossed nicols is due to transmitted polarized light may be demonstrated :

(a) By cutting off all extraneous light which could be reflected from the upper surface of the section, when its aspect remains unaltered;

(b) By placing the principal sections of the nicols parallel, when the appearance closely resembles that seen when ordinary transmitted light is employed ;

(c) By using ordinary reflected light, the section having then nearly the same appearance as when viewed between crossed nicols.

$\mathbf{H}_{40}$. Rotorua-A white to yellowish-white siliceous deposit with a conchoidal fracture, and in most parts showing a waxy lustre, in other parts dull and pulverulent.

Under the microscope, the section exhibits a rough and somewhat irregularly-banded structure. The different bands vary in character, some appearing like vitreous matter speckled with small translucent bodies, at first sight suggestive of globulites, but they are not spherical as a rule. In other bands these small bodies are so densely packed that the bands are far less translucent. Some of the darker bands seem to have been rendered quite spongy through the presence of numerous irregular cavities, now filled with colourless doubly-refracting matter which, on rotation between crossed nicols, appears to be hyalite : the globular forms which line the

1 'Geological Report on Isle Royale' by Alfred C. Lane, Geol. Surv. Mich. vol. vi, pt. i (1898) pp. $168,171,175$.

2 The specimen is one of several collected by Mr. G. F. Rodwell, to whose generosity $\mathrm{I}$ am indebted for these and other Icelandic specimens.

3 A very similar appearance is also to be noted in some devitrified obsidians, when viewed in reflected light. 
walls of some of these cavities renders such an assumption more than probable. The optical character of the substance almost wholly constituting this section agrees perfectly with that previously described as characteristic of geyserite. This specimen indeed seems to be a remarkably pure example, since after powdering and drying it at $100^{\circ} \mathrm{C}$., Mr. Philip Holland found the percentage of silica to be 93.59. Some idea of the probable nature of the other constituents may be gathered from an analysis, by J. W. Mallet, of a siliceous deposit from the hot springs of Lake Taupa ${ }^{1}$

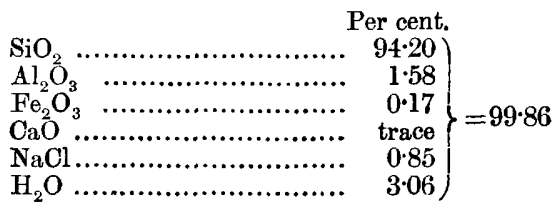

In one of the more translucent bands in this section there may be found evidence of diatoms, apparently similar to those commonly met with in deposits of tripoli. An amplification of about 250 diameters is, however, necessary before the existence of these small bodies can be recognized.

$\mathrm{H}_{41}$. Ro tor u a. - A compact se mi-o p a l, with waxy to sub-vitreous lustre and conchoidal fracture. It has a rude, irregularly-banded structure, one band being reddish-brown and the rest bluish-grey.

Under the microscope, the section is mainly isotropic between crossed nicols, and exhibits no appreciable structure. A few specks, apparently of pyrites, and numerous doubly-refracting grains, without any definite crystal-boundaries or cleavages, are present.

The reddish portions apparently owe their colour to hæmatite in a very fine state of division. A very obscure fibrous structure may be present in places.

$\mathrm{H}_{42}$. Rotorua.-Rock consisting of white fragments, most of them apparently felspathic, embedded in a matrix or cement which is in part light bluish-grey and crystalline, in part dark or almost black. The specimen looks like a rather coarse breccia. On a cut surface, some of the white fragments show very small cavities, generally elongated and suggestive of irregular furrows.

Under the microscope, the section is seen to consist chiefly of lapilli of pumice, a few fragments of rock, possibly rhyolite, some of these being opaque and pink, others reddish-brown in transmitted light, and all more or less corroded superficially. There are also fragments of crystals, upon the original nature of which it is impossible to speculate, since they do not show definite crystalboundaries or any cleavages: they are traversed by irregular cracks, and are practically isotropic. The section also contains a fragment of quartz. The whole of these fragments are bordered by hyalite, the remainder of the rock being filled in by isotropic silica

I Phil. Mag. vol. $\vee(1853)$ p. 285; also quoted in Hochstetter's 'New Zealand' transl. E. Sauter (Stuttgart, 1867) p. 435. 
or geyserite. (See Pl. XXVII, fig. 6.) Between crossed nicols the hyalite shows the usual double refraction due to tension, broken by an irregular series of dark brushes (parts of dark crosses). The contrast between the hyalite and the isotropic opal-silica is very marked.

$\mathrm{H}_{43^{*}}$ Rotorua.-A brecciated rock resembling $\mathrm{H}_{42}$, just described, but apparently more altered by solfataric action.

Under the microscope, the fragments which give the brecciated character to this rock are seen to be almost wholly pumice; still there are a fow fragments in the section as to the nature of which there must be considerable doubt. Probably they are lapilli of rhyolite, very much honeycombed by the hydrothermal action to which they have been subjected. The cementing material is amorphous opalsilica. The fragments do not possess the broad hyalitic borders which surround the fragments in the rock previously deseribed $\left(\mathrm{H}_{42}\right)$. The lapilli in the breccia, other than those of pumice, have evidently undergone considerable alteration, especially as regards their included crystals of felspar. The total percentage of silica present in this rock, after drying the powder at $100^{\circ} \mathrm{C}$., has been estimated by Mr. Philip Holland as $87 \cdot 89$.

$\mathrm{H}_{44}$. Rotorua.-A pink granular rock, easily rubbed to a very fine powder which feels harsh and gritty between the fingers.

Under the microscope, the section appears to consist mainly of extremely fine pumice-dust and amorphous silica, rendered porphyritic in aspect by lapilli of perlitic obsidian and pumice. The section is flecked by numerous irregular dots, patches, and sporadic irregular veins of a substance which in transmitted light seems nearly opaque and of a dark reddish-brown. When examined in reflected light, it is seen to be bright vermilion. The colour is more suggestive of cinnabar than hæmatite, but, when the substance is heated in a closed tube with dry carbonate of soda, no satisfactory evidence of the presence of mercury is to be detected. The suspicion that mercury might have been present was increased by the circumstance that cinnabar is sometimes found in connection with hot springs as a result of solfataric action, ${ }^{1}$ and that its occurrence in New Zealand has already been noted.

The total percentage of silica in this rock, when powdered and dried at $100^{\circ} \mathrm{C}$., was found by Mr. Holland to amount to $77 \cdot 79$. He also examined it for mercury, but failed to detect any; he found, however, 0.07 per cent. of organic matter. ${ }^{2}$

1 Dana's 'System of Mineralogy' 6th ed. (1892) p. 67.

$2 \mathrm{Mr}$. Holland informs me that he treated a weighed portion of this rock with re-distilled and dry chloroform, and the filtered extract was colourless. The extract, on filtration and distillation, left a slight waxy residue which, heated over a flame on platinum-foil, gave off a resinous odour. The amount of this waxy matter was not more than 0.07 per cent., as stated above. Mr. Holland noted a similar odour on heating a paraffinoid substance, which he extracted some years ago by means of chloroform from black Scotch peat. He states that the pink colour of this sinter is due to ferric oxide. 
$H_{45}$. Rotorua.-A grey to yellowish-white rock, with spherulitic structure, and showing in places a small amount of hyalite. The rock has a cavernous or honeycombed aspect due to solfataric action. ${ }^{1}$

Under the microscope this rock is seen to be an altered spherulitic obsidian, consisting almost entirely of spherulites of the large brown microfelsitic type, similar to those met with at Mercury Bay, except that these have undergone great change, while those of Mercury Bay are practically unaltered. The whole rock, indeed, appears to have been intensely affected by solfataric action. In many places the spherulites are partly, in others almost wholly bleached, the irregularly-shaped, brown, unaltered portions imparting an almost brecciated appearance to the section, when viewed in ordinary transmitted light.

The alteration of these spherulites is apparently of the same nature as that of the spherulites in the 'older rhyolite' of Waihi Beach $\left(\mathrm{H}_{31}\right)$ described on pp. $498-499$ of this paper, but the change does not appear to have been carried quite so far as in the Waihi rock. The nature of the alteration seems to consist in the gradual substitution of silica for portions of the spherulites which have been dissolved: the process of molecular substitution having apparently gone on with great exactitude, as in the silicification of wood, the fibrous structure of the spherulites being beautifully preserved. (See Pl. XXVII, fig. 5.) An interesting feature of the change lies in the circumstance that, although the replacing substance was opal-silica, the altered parts of the spherulites exhibit the same double vefraction between crossed nicols as those parts of the spherulites which remain brown and unaltered. The dark crosses pass through altered and unaltered parts of the spherulites without any appreciable break or modification. It seems possible that the mere fact of isotropic opal-silica replacing a fibrous structure suffices to impart double refraction, no matter whether the replaced fibre was anisotropic or not. Support is lent to this hypothesis by the feeble double refraction shown by fibres of glass ('spun glass'), the extinction taking place in the direction parallel to the length of the fibre. Again, in a section made from the white pulverulent crust on the surface of a specimen of silicified wood (wood-opal) from Tasmania, the fibrous structure of the woody tissue appears brilliantly illuminated when the fibres are placed at $45^{\circ}$ to the principal sections of the crossed nicols, and becomes extinguished when these are turned parallel and at right angles to the length of the fibres. It is clear, therefore, that opal-silica, whether it replaces the fibres of woody tissue or the fibres of a spherulite, develops the phenomenon of double refraction.

The spaces between the spherulites in this Rotorua rock are flled with opal-silica. Where this has been deposited on the surface of a spherulite, it has often assumed the condition of hyalite, exhibiting,

1 I am indebted for this specimen to the kindness of Mr. A. Vaughan Jennings, F.L.S., F.G.S., who procured it when visiting Rotorua in 1890. 
in ordinary transmitted light, the mammillated surface, and, in polarized light, the double refraction characteristic of that variety of opal. Those parts of the section which lie between spherulites frequently contain some silica which is, as a rule, perfectly isotropic, save for a few bright doubly-refracting specks. In a few places in the section, some nearly opaque matter occurs. It usually forms thin irregular lines which have the appearance of lining cavities or filling cracks. In reflected light this substance has a rather strong pink colour, but concerning its nature or the pigment to which it owes its colour it seems unsafe to speculate. The silica-percentage of this rock is found by Mr. Philip Holland to be $75 \cdot 90$.

$\mathrm{H}_{4 \mathrm{6}}$. Rotorua.-Part of a dark-grey bo mb, ejected during the eruption of Tarawera in 1886. ${ }^{1}$ The form of this bomb was evidently all but spherical and, when entire, it measured probably between 2 and 3 inches in diameter.

Prof. A. P. W. Thomas, F.L.S., F.G.S., of University College, Auckland, has so well described the rock of which these bombs consist, that I cannot do better than quote his words :

- Under the microscope thin slices of the rock show rather numerous small crystals of felspar and yellowish augite. The felspars are mostly small and in ledge-shaped sections, but a few rather larger ones are present; they are nearly all plagioclases, but there are a few distinct sanidines. The augite is in small irregular crystals and granules. The ground nass of the rock is a grey glass with abundant crystallites (globulites, longulites, and microliths) of translucent substance, and grains of magnetite. Much of the augite should perhaps be considered as belonging to the groundmass.' ${ }^{2}$

To this description there seems nothing to add. The section now examined, although by no means so thin as could be wished, sufficiently confirms all that Prof. Thomas says. He further adds:

'Olivine was found in a few small crystals in some specimens, but as a rule it is quite absent.'

Discussing the precise character of the rock, he also says (loc. cit.):

' On account of the absence of olivine as an essential constituent, the presence of abundant glass with microliths, and of a little sanidine, the rock has been identified as an augite-andesite. Still, it must be admitted that the rock approximates to the basalts, as is further shown by its chemical analysis... The percentage of silica varies from 50.9 to 52.5 , an amount which is lower than that usually found in augite-andesites, whilst it is not higher than that found in some basalts. But whether we call the rock an augite-andesite or a basalt without olivine, does not affect the results stated above, that the lava of the late eruption is basic, is new to the locality, and follows the acid rhyolites.'

From the resemblance which the section of this bomb bears to some of the Icelandic basalts without olivine, it seems probable that Prof. Thomas is perfectly justified in regarding the rock as a basalt.

1 For this specimen I an indebted to Mr. G. F. Rodwell, who visited the scene of the eruption in 1887.

2 ' Report on the Eruption of Tarawera \& Rotomahana, N.Z.' (Wellington, 1888) p. 58 . 
The analyses of it, which he cites, made by Mr. J. A. Pond, Colonial Analyst, Auckland, are :-

\begin{tabular}{|c|c|c|c|}
\hline $\begin{array}{lll}\mathrm{SiO}_{2} \\
\mathrm{FeO} \\
\mathrm{Al}_{2} \mathrm{O}_{3} \\
\mathrm{Ca}_{2} \mathrm{Fe}_{3}\end{array}$ & $\begin{array}{c}\text { I. } \\
\text { Per cent. } \\
50 \cdot 90 \\
14 \cdot 10 \\
20 \cdot 00 \\
10 \cdot 38 \\
2.77 \\
\cdot 70 \\
\cdot 14 \\
\cdot 04 \\
.20 \\
\cdot 16 \\
60 \\
60 \\
\text { trace. }\end{array}$ & $\begin{array}{c}\text { II. } \\
\text { Per cent. } \\
51 \cdot 35 \\
14 \cdot 50 \\
18 \cdot 20 \\
10 \cdot 26 \\
3 \cdot 10 \\
\cdot 835 \\
\cdot 16 \\
\cdot 05 \\
\cdot 41 \\
\cdot 125 \\
\cdot 60 \\
\text { trace. }\end{array}$ & $\begin{array}{c}\text { III. } \\
\text { Per cent. } \\
52 \cdot 50 \\
12 \cdot 70 \\
18 \cdot 20 \\
11 \cdot 05 \\
4 \cdot 65 \\
\cdot 67 \\
\cdot 09 \\
.05 \\
.32 \\
\cdot 06 \\
- \\
\text { trace. }\end{array}$ \\
\hline & $100 \cdot 01$ & 9959 & 10029 \\
\hline
\end{tabular}

I. Lapilli (augite-andesite), Wairoa.

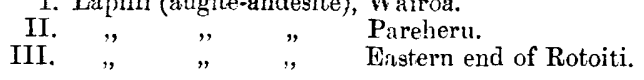

$\mathrm{H}_{47}$. Rotorua.-A dark-grey to black obsidian, profusely speckled with yellowish-white crystalline or finely-granular spots.

Under the microscope, occasional porphyritic crystals of felspar are to be seen, sometimes entire, at others in fragments. For the most part they are sanidine, but there are also a few which show lamellar twinning and appear in one or two instances, from their extinction-angles, to be labradorite. The extinction in these felspars is often zonal, and they are more or less corroded and traversed by irregular cracks. Isolated dark-bromn spherulites are also present in the section. These hare occasionally been formed about a fragment of felspar. Some grains of magnetite occur, but they are not numerous. This obsidian is filled with globulites and longulites. One or tro delicate, yellowish-brown, rod-like sections of crystals may be seen in this slide : their appearance suggests biotite, but they show inclined extinction and are probably hornblendes with a low extinction-angle of ahout $5^{5}$. A delicate fluxion-banding may be seen in some parts of the section.

\section{Conclusions.}

A consideration of the microscopic characters presented by the rhyolitic rocks of New Zealand, and of the alterations which they have experienced, especially through solfataric action, naturally leads to the enquiry whether the ancient rhyolites of Great Britain give evidence of similar changes.

We may, indeed, regard the rhyolitic laras of New Zealand as one of the most recent text-books upon this subject, and it behoves geologists to make what use they can of such a source of information by endeavouring to ascertain whether our own old rhyolites can yield us some further clue to the conditions, which not merely accompanied their eruption and brought about their 
alteration, but also whether the latter was in any way due to solfataric action; in other words, whether hot springs and geysers originally existed in the areas where British rhyolites are found.

It cannot at this moment be positively affirmed that we have any evidence of this kind; but a comparison of thin sections of our older rhyolites with those of New Zealand lead to the belief that careful study in this direction will eventually prove that some, at least, of our older rhyolites have been more or less affected by solfataric action. So far I have failed to find any positive evidence upon this point; and I can only mention one or two instances in which sections examined in reflected, as well as in polarized and ordinary transmitted, light have aroused some suspicion.

One case is that of a rock from the northern end of Dufton Pike in Westmoreland. A section of somewhat similar rock has already been described by Mr. A. Harker' under the heading 'Rhyolitic Rocks,' in Appendix I to Marr \& Nicholson's paper on 'The Cross Fell Inlier.' This section. when examined in reflected light, seemed to show a very close resemblance to some siliceous sinters; but this similarity of appearance is hardly to be trusted, since formerly vitreous acid lavas, now devitrified, often present a like aspect, when viewed in reflected light. On submitting part of this specimen to Mr. Philip Holland, he informed me that the total silica in it amounts to only 69 per cent.: a circumstance which strongly supports Mr. Harker's opinion that the rock is a rhyolite. ${ }^{2}$

Another specimen from Carneddau, near Builth, has a brecciated aspect, and so closely resembles $H_{42}$ from Rotorua (p. 504) that a comparison of the sections seemed desirable. Under the microscope, the Carneddau rock is seen to consist of angular fragments of felsite, held together by a brownish cement which still contains much isotropic matter, possibly to be regarded as siliceous sinter somewhat altered. The felsitic fragments show none of the structures characteristic of rhyolites, although such structures may originally have been present.

As to the causes which may convert a glassy into a lithoidal rhyolite, we still seem to lack information; but, as I have suggested in a former paper read before this Society, it is possible that the action of steam may be instrumental in such a change. This, however, is probably only an occasional agent, and the more general cause of such changes must be sought elsewhere.

In microscopic characters the rhyolitic rocks of New Zealand represent, structurally, everything met with in our ancient rhyolites, apart from the alteration which some of the latter have undergone.

The obliteration of original structures by the development of a felsitic condition, as illustrated in the spherulitic rhyolite of Waihi Beach, may account for the comparatively structureless character of some of our old rhyolites, such, for instance, as a considerable

1 Quart. Journ. Geol. Soc. vol. xlvii (1891) p. 518.

2 Mr. Harker expresses very guardedly his opinion concerning the groundmass of this rock, which deserves further examination.
Q.J. G. S. No. 223. 
proportion of those occurring at Caradoc; and it does not seem unreasonable to suspect that where felsitic lavas are found to be comparatively devoid of fluxion-banding, spherulitic, and other structures so commonly met with in rhyolites, solfataric action may have been instrumental in bringing those rocks to their present condition.

\section{EXPLANATION OF PLATE XXVII.}

Fig. 1. Mayor Island $\left[\mathrm{H}_{26}\right]$ - - Obsidian containing gas-inclusions, small crystals of hornblende, and microlites of felspar. $\times 140$. Ordinary transmitted light. (See p. 495.)

2. Waitekauri $\left[\mathrm{H}_{27}\right]$.-Perlitic obsidian. $\times 30$. Ordinary transmitted light. (See p. 496.)

3. Waihi Beach $\left[\mathrm{H}_{31}\right]$.-Devitrified spherulitic obsidian, some of the spherulites being partly altered to felsite. $\times 30$. Ordinary transmitted light. (See p. 498.)

4. The same portion of the section as that shown in fig. $3 . \times 30$. Polarized light (crossed nicols).

5. Rotorua $\left[\mathrm{H}_{15}\right]$. - Spherulitic rhyolite, altered by solfataric action. $\times 30$. Ordinary transmitted light. In this figure only vestiges of the brown spherulites are seen, but, between crossed nicols, the spherulites appear entire, as if no portion of them had been altered. (See p. 506.)

6. Rotorua $\left[\mathbf{H}_{42}\right]$.-Pumice-tuff, consisting of lapilli of pumice and altered rhyolite? (the latter are not shown in the figure), bordered and cemented by hyalite. $\times 30$. Ordinary transmitted light. (See p. 504.)

Discussion.

The Presmont said that all the Fellows present would regret extremely the absence of the Author, and still more the cause of that absence. He (the President) had recently examined an extensive series of felsites (rhyolites) and jaspers occurring as pebbles in the Torridonian rocks of Scotland, and had come to the conclusion that the jaspers were in many cases silicified rhyolites. He would now be able to quote the present paper as additional evidence of this conclusion.

Mr. Frederick Chapman remarked upon the occurrence of the thread-like bodies in the siliceous rocks of Rotorua, which may possibly be comparable with the filamentous algæ described by Weed from Yellowstone Park and referred by that author to Leptothrix, etc. It was also of considerable interest to notice the presence of diatoms in the sinters. From a general examination, the frustules which had their outlines best preserved seemed to belong to the genera Melosira and Epithemia, and possibly Orthosira was present.

Mr. HARKER remarked on the close resemblance between the rhyolites and sinters of New Zealand and those of the Yellowstone Park. The Author's suggestions might also throw light on the origin of certain ancient British rocks, which have probably undergone silicification by solfataric action; but here the results are complicated by the subsequent conversion of the amorphous silica into quartz. Certain rocks in Westmoreland, Caernarvonshire, and Pembrokeshire, consisting essentially of microcrystalline quartz, still preserve the characteristic structures of rhyolitic lavas.

Prof. Watrs also spoke. 
Quart joum.Geol.Soc.Vol.I.VI PI.XXVII.

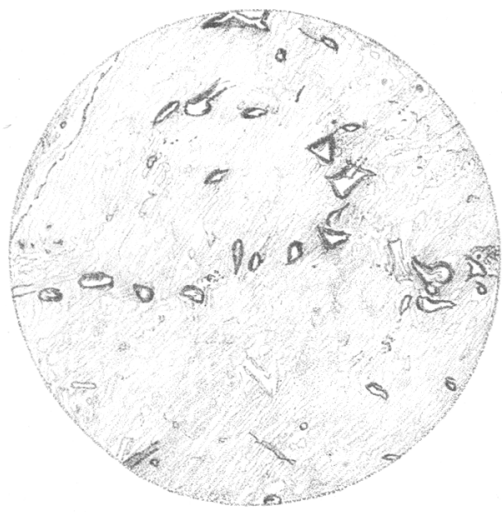

$1(\times 140)$
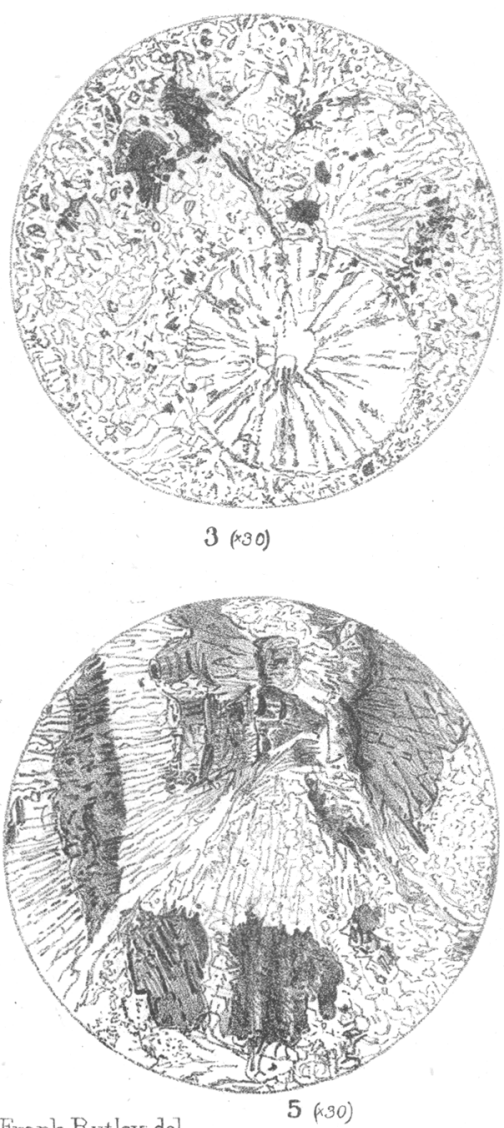

Frank Rutley del $5(\times 30)$
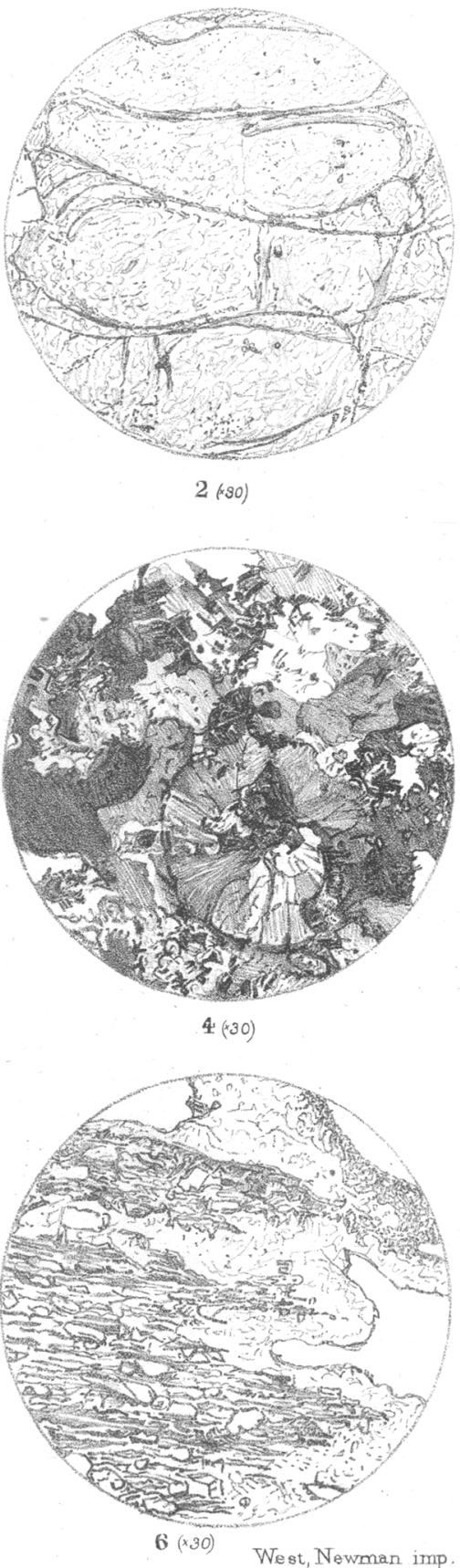
West, Newman imp.

E.Drake hth 